\title{
Indoor Measurement of Angle Resolved Light Absorption by Black Silicon
}

Amdemeskel, Mekbib Wubishet; landolo, Beniamino; Davidsen, Rasmus Schmidt; Hansen, Ole; Benatto, Gisele Alves dos Reis; Riedel, Nicholas; Poulsen, Peter Behrensdorff; Thorsteinsson, Sune; Thorseth, Anders; Dam-Hansen, Carsten

Published in:

Proceedings of the international 2017 IEEE Photovoltaic Specialists Conference

Publication date:

2017

Document Version

Publisher's PDF, also known as Version of record

Link back to DTU Orbit

Citation (APA):

Amdemeskel, M. W., landolo, B., Davidsen, R. S., Hansen, O., Benatto, G. A. D. R., Riedel, N., Poulsen, P. B., Thorsteinsson, S., Thorseth, A., \& Dam-Hansen, C. (2017). Indoor Measurement of Angle Resolved Light Absorption by Black Silicon. In Proceedings of the international 2017 IEEE Photovoltaic Specialists Conference IEEE.

\section{General rights}

Copyright and moral rights for the publications made accessible in the public portal are retained by the authors and/or other copyright owners and it is a condition of accessing publications that users recognise and abide by the legal requirements associated with these rights.

- Users may download and print one copy of any publication from the public portal for the purpose of private study or research.

- You may not further distribute the material or use it for any profit-making activity or commercial gain

- You may freely distribute the URL identifying the publication in the public portal 


\title{
Indoor Measurement of Angle Resolved Light Absorption by Black Silicon
}

\author{
Mekbib W. Amdemeskel ${ }^{1}$, Beniamino Iandolo ${ }^{2}$, Rasmus S. Davidsen ${ }^{2}$, Ole Hansen ${ }^{2}$, Gisele A. dos Reis \\ Benatto $^{1}$, Nicholas Riedel ${ }^{1}$, Peter B. Poulsen ${ }^{1}$, Sune Thorsteinsson ${ }^{1}$, Anders Thorseth ${ }^{1}$, Carsten Dam- \\ Hansen $^{1}$ \\ ${ }^{1}$ Department of Photonics Engineering, Technical University of Denmark, Frederiksborgvej 399, 4000 \\ Roskilde, Denmark, mekwub@fotonik.dtu.dk \\ 2 Department of Micro- and Nanotechnology, Technical University of Denmark, Ørsteds P1., 2800 \\ Kongens Lyngby, Denmark
}

\begin{abstract}
Angle resolved optical spectroscopy of photovoltaic (PV) samples gives crucial information on PV panels under realistic working conditions. Here, we introduce measurements of angle resolved light absorption by $P V$ cells, performed indoors using a collimated high radiance broadband light source. Our indoor method offers a significant simplification as compared to measurements by solar trackers. As a proof-of-concept demonstration, we show characterization of black silicon solar cells. The experimental results showed stable and reliable optical responses that makes our setup suitable for indoor, angle resolved characterization of solar cells.
\end{abstract}

\section{INTRODUCTION}

The short circuit current output of solar cells under working conditions is affected by several factors. In particular, the effect of angle of incidence (AOI) on the optical properties, and therefore on the short circuit current, is considerable for AOI beyond $45^{\circ}$ and needs to be taken into account when assessing performance of solar cells. Reindl et al. investigated the effect of diffuse irradiation as function of irradiation angle using four different models [1]. The effect of angle of incidence (AOI) on performance of crystalline silicon (c-Si) solar cells was studied as a function of irradiation angle by King et al. [2]. A comparison of angle resolved optical characterization of black Si solar cells with conventionally textured Si solar cells was recently presented by Davidsen et al. [3], however this work presented data on raw cells. In this work, we take a further step towards characterizing black Si based PV panels in working conditions by measuring short circuit current as function of incidence angle on encapsulated, one cell mini modules. In a more general perspective, we have built a set-up that allows automatized, reliable measurements of the short circuit current of solar cells as function of incidence angle with collimated, simulated sunlight. This indoor set-up has several advantages over measuring the AOI effect outdoors on a tracker: (i) the measurements are not compromised by the effects of atmospheric diffuse or ground reflected light; (ii) the spectrum and intensity of the light source remain constant throughout the test; and (iii) the rotation stage can move easily and accurately within $-90^{\circ}$ and $+90^{\circ}$ AOI. Furthermore, indoor measurements using light sources such as flash lights are highly affected by the divergence of the beam. In contrast, the light source used here provides bright illumination across the UV-VIS-NIR range together with high spatial and power stability. In addition the light source is well collimated by collection optics to give a stable and reliable power measurement. PV simulation tools such as the familiar PVsyst describe the optical losses from increased AOI as an "incidence angle modifier" (IAM). In our final submission we will use the measured IAM data in PVsyst simulations and share energy production estimates of black $\mathrm{Si}$ and $\mathrm{c}-\mathrm{Si}$ with standard (non-AR) glass across latitudinal locations.

\section{EXPERIMENTAL METHOD}

Black Si based solar cells were fabricated on p-type wafers as previously described [3], using a maskless reactive ion etch (RIE) process to texture the Si surface. In brief, the following steps were followed: (1) saw damage removal by etching in 30 $\% \mathrm{KOH}$ at $75^{\circ} \mathrm{C}$ for 2 min followed by cleaning in $20 \% \mathrm{HCl}$ at room temperature for $5 \mathrm{~min}$ and rinsing using deionized water; (2) Maskless RIE at room temperature in a plasma with $\mathrm{O}_{2}: \mathrm{SF}_{6} \approx 1: 1$ gas flow ratio, chamber pressure of $28 \mathrm{mTorr}$, 13.56 MHz radio-frequency and platen power of $30 \mathrm{~W}$, (STS RIE); (3) Emitter formation using a tube furnace (Tempress Systems) with liquid $\mathrm{POCl}_{3}$ as dopant source and $\mathrm{N}_{2}$ as carrier gas at $840{ }^{\circ} \mathrm{C}$ and atmospheric pressure for $50 \mathrm{~min}$, followed by removal of phosphor-silicate glass (PSG) in $5 \%$ hydrofluoric acid (HF); (4) Plasma enhanced chemical vapor deposition (PECVD) of $60 \mathrm{~nm}$ hydrogenated amorphous silicon nitride ( $\mathrm{SiNx}: \mathrm{H})$ anti- reflective coating at $400{ }^{\circ} \mathrm{C}$ using a PlasmaLab System 133 (Oxford Instruments); (5) Screen-printing of $\mathrm{Ag}$ front and $\mathrm{Al}$ rear contacts with standard $\mathrm{Ag}$ and $\mathrm{Al}$ pastes using an EkraX5-STS screen printer, followed by co-firing of the front and rear contacts at $800{ }^{\circ} \mathrm{C}$ using a RTC Model LA-309 belt furnace; (6) Edge isolation by laser ablation using a J-1030-515-343FS System (Oxford Lasers Ltd). For the encapsulation, ribbons were soldered on the solar cell and a standard lamination procedure was performed at $160{ }^{\circ} \mathrm{C}$ following the EVA (ethylene vinyl acetate) film manufacturer's recommendations, with a stack 
consisting of $4 \mathrm{~mm}$ low iron glass, $450 \mu \mathrm{m}$ EVA, the cell, 450 $\mu \mathrm{m}$ EVA, and a black colored TPT back-sheet.

Angle resolved absorption measurements of the black silicon cells were performed using the set-up sketched in Fig. 1(a). A laser driven light source (LDLS) EQ-99FXC (Energetiq Technology, Inc.) with spectral emission between 190 and $2100 \mathrm{~nm}$, collimated using an off-axis parabolic mirror, was used together with a UV filter, a sample holder stepper motor (THORLABS-NR360S) and a LABVIEW controlled short circuit current $\left(\mathrm{I}_{\mathrm{sc}}\right)$ measuring transducer with an impedance of $25 \mathrm{ohms}$. The UV filter was positioned immediately after the light source in order to remove the UV$\mathrm{C}$ part. The spectrum of the LDLS with and without filter in comparison with the solar spectrum is shown in Fig. 2. The measurement room was kept at a temperature of $21^{\circ} \mathrm{C}$ using an air conditioning system.

(a)
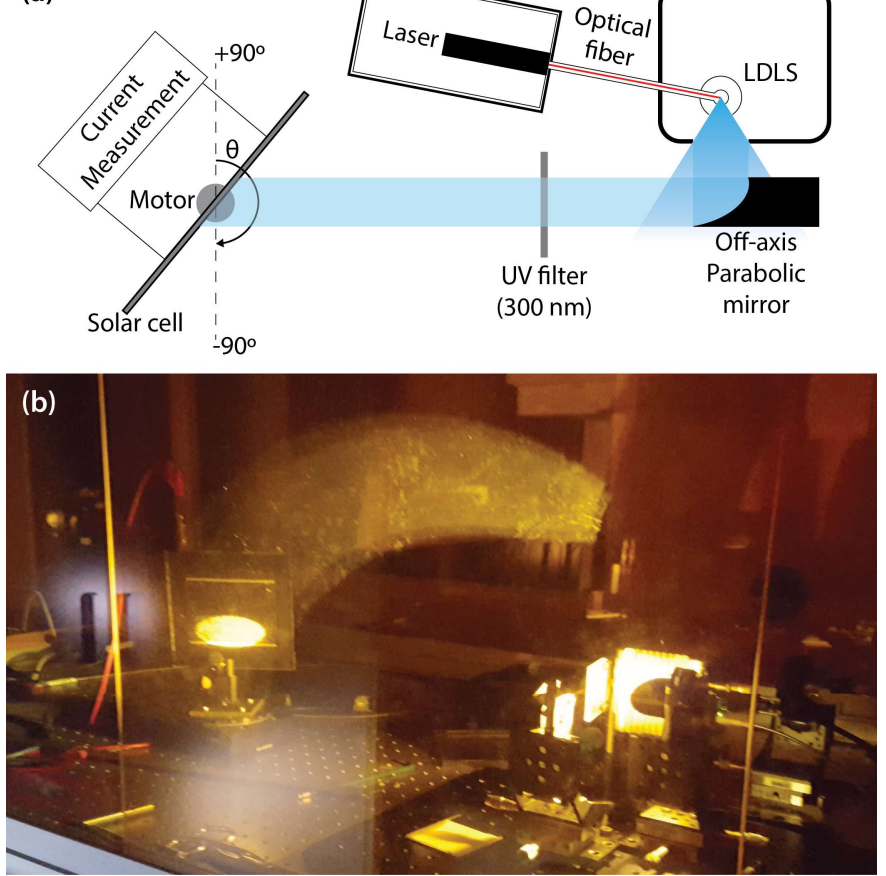

Fig. 1 Top view Schematic (a) and photograph (b) of the setup for measuring angle resolved absorption.

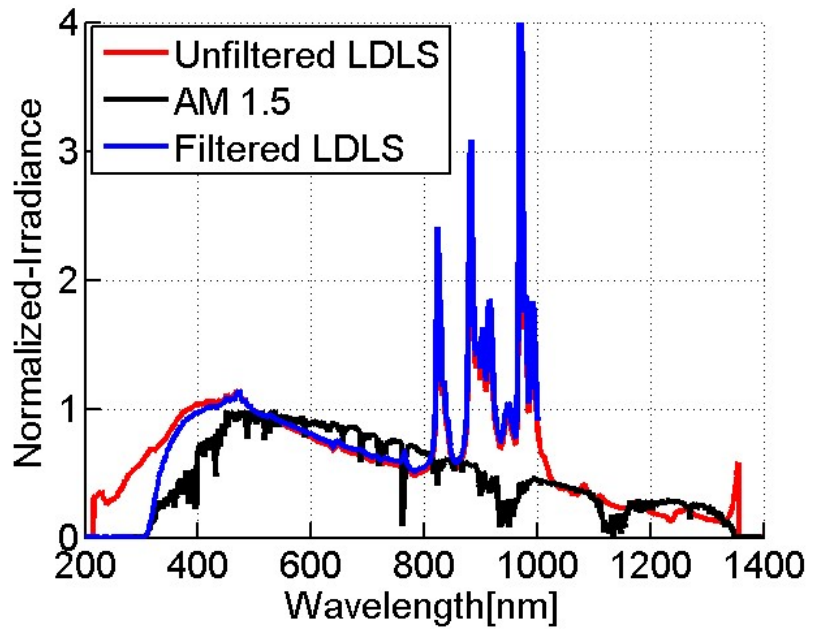

Fig. 2 The sun, filtered and unfiltered LDLS spectrum normalized to sun peak wavelength.

The AOI was changed by rotating the solar cells using a stepper motor around the vertical axis. The AOI are indicated with respect to normal incidence. The electrical transducer together with LABVIEW station was used to measure the $\mathrm{I}_{\mathrm{sc}}$ for AOI between $90^{\circ}$ to $-90^{\circ}$ with a $5^{\circ}$ step size.

\section{RESULTS AND DISCUSSION}

Short circuit current versus angle of incidence $\left(\mathrm{I}_{\mathrm{sc}}-\mathrm{AOI}\right.$, or $\left.\mathrm{I}_{\mathrm{sc}}-\theta\right)$ curves were obtained for two different black Si based samples Fig. 4 (a). We have performed an initial reproducibility test by repeatedly acquiring $\mathrm{I}_{\mathrm{sc}}-\mathrm{AOI}$ curves for the same samples. Results are summarized in Fig. 3. In particular, we determined the highest standard deviation of $\mathrm{I}_{\mathrm{sc}}$ to be $0.7 \mathrm{~mA}$ for AOI larger than $\pm 80^{\circ}$.

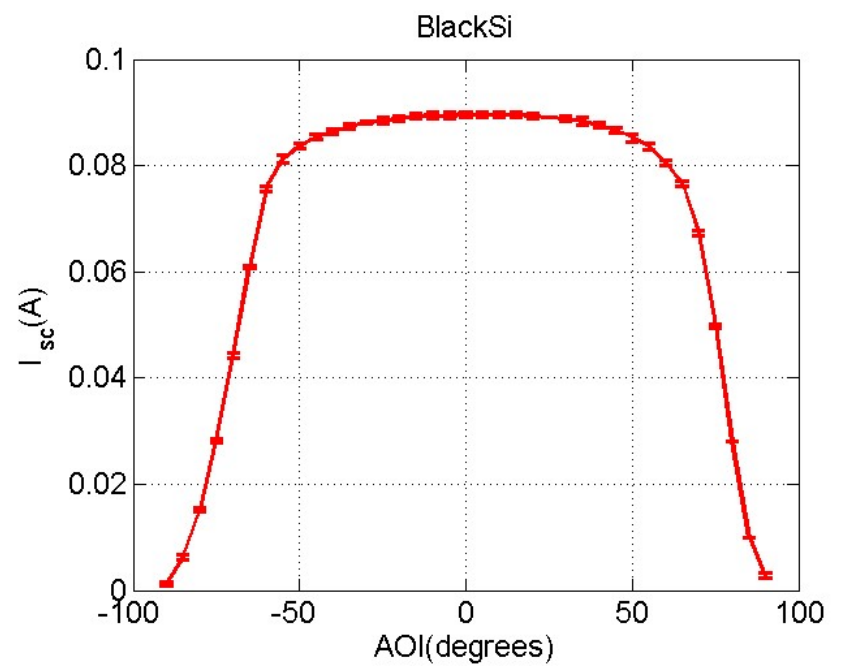

Fig. 3 AOI-Isc plot for reproducibility of our measurement setup with error bar showing the standard deviation of the current for each angular step. 
It is worth mentioning that, for AOI larger than $\pm 75^{\circ}$, not all the light beam hits the solar cell, as can be seen in Fig. 4(b) and (c). Therefore, we have computed an area i.e. power correction factor (it is calculated by dividing the partial area of the beam on the cell by the full elliptical area of the beam as shown in Fig. 4 (b) and (c)) for the partial beam spot to recalculate the actual reduced power reaching the cell from the total power (full spot area). This area correction for large angles is similar to the standard cosine correction for measurements setups where the spot size is larger than the cell.

Once corrected by the area factor, $\mathrm{I}_{\mathrm{sc}}$ was normalized to the value at the normal angle incidence, i.e. for AOI $=0^{\circ}$. Since we are using a collimated light source, we have neglected the diffuse component. Thus for this setup the normalized and area corrected current is in fact the Incident Angle Modifier (IAM) used in e.g. PV-syst. We characterized two black silicon cells, and the IAM for these samples is shown in Fig. 5. The graphs look very similar, with only a very slightly faster decay at larger AOI for sample 1. Future work will for instance include characterization of cells fabricated with other methods (e.g. silicon textured by conventional, wet etch methods) for comparison with black silicon cells.

\section{(a)}

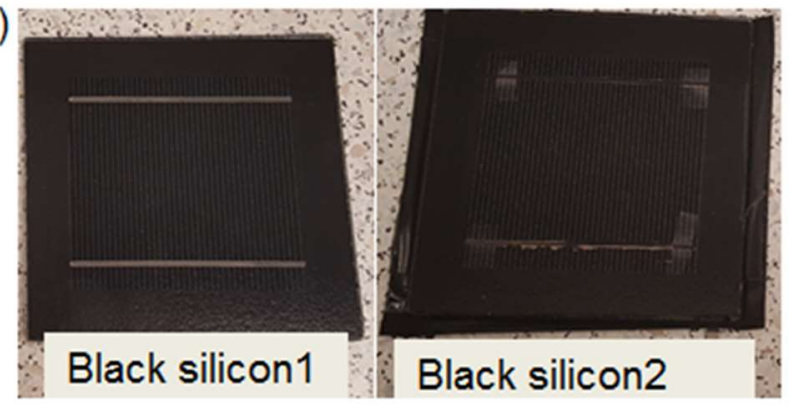

(b)
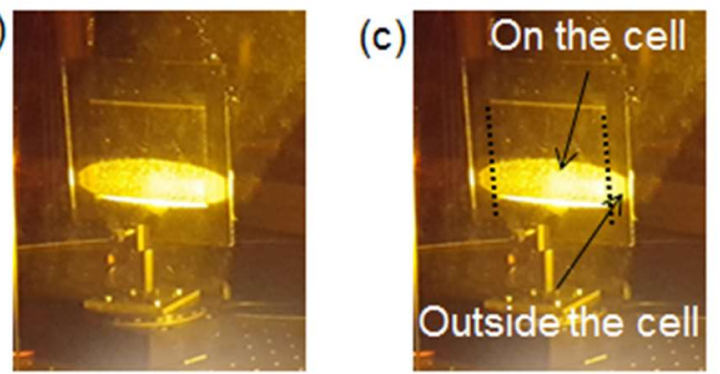

Fig. 4 Photograph showing the two black silicon solar cells (a) and illustration of portion of the beam missing the solar cell for AOI larger than $\pm 75^{\circ}$.

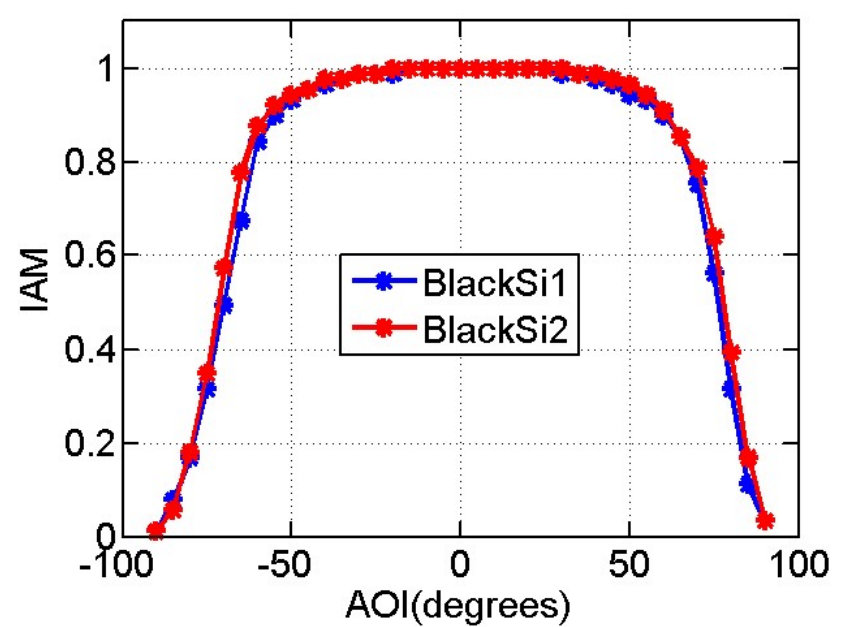

Fig. 5 IAM-AOI plot for the two black silicon solar cells

\section{CONCLUSIONS}

In conclusion, we presented here an indoor study on the effect of the angle of incidence on the short circuit current of encapsulated, black silicon based solar cells, using a broadband, collimated light source. In a wider perspective, our setup allows for automatized, reliable measurements of short circuit current for AOI between $+90^{\circ}$ and $-90^{\circ}$ and is not restricted to measurements on black silicon. Results indicate the setup to be a viable method for determining the IAM. Importantly, reproducibility on the AOI was very high with a maximum average standard deviation of $0.7 \mathrm{~mA}$. Future work includes more measurements on standard cells for validation of the method and systematic tests allowing for determination of the angular performance for black silicon encapsulated cells in combination with different types of glasses (ARC coated and structured). The setup presented here is a valuable tool for indoor measuring the IAM i.e. the angular performance on solar cells and mini modules.

\section{REFERENCES}

[1] D. T. Reindl, W. A. Beckman, and J. A. Duffie, "Evaluation of hourly tilted surface radiation models," Sol. Energy, vol. 45, no. 1, pp. 9-17, 1990.

[2] D. L. King, J. A. Kratochvil, and W. E. Boyson, "Measuring solar spectral and angle-of-incidence effects on photovoltaic modules and solar irradiance sensors," Conf. Rec. Twenty Sixth IEEE Photovolt. Spec. Conf. - 1997, no. September, pp. 1113-1116, 1997.

[3] R. S. Davidsen, J. Ormstrup, M. L. Ommen, P. E. Larsen, M. S. Schmidt, A. Boisen, Ø. Nordseth, and O. Hansen, "Angle resolved characterization of nanostructured and conventionally textured silicon solar cells," Sol. Energy Mater. Sol. Cells, vol. 140, pp. 134-140, 2015. 